\title{
A 100-year record of climate change and human activities inferred from the geochemical composition of sediments in Chaiwopu Lake, arid northwest China
}

\author{
Wen LIU, ${ }^{1}$ Jinglu WU, ${ }^{2 *}$ Xiangliang PAN ${ }^{1}$ \\ ${ }^{1}$ State Key Laboratory of Desert and Oasis Ecology, Xinjiang Institute of Ecology and Geography, Chinese Academy of Sciences, \\ Urumqi 830011; ${ }^{2}$ State Key Laboratory of Lake Science and Environment, Nanjing Institute of Geography and Limnology, Chinese \\ Academy of Sciences, Nanjing 210008, China \\ *Corresponding author: w.jinglu@niglas.ac.cn
}

\begin{abstract}
An 81-cm sediment core from Chaiwopu Lake in arid northwest China was analyzed for ${ }^{137} \mathrm{Cs}$ activity and concentrations of major and trace elements. We used these data to discriminate between the influence of climate change and human activities on the geochemical change of the lake sediments over the past century. Elements Al, K, Ba, Ti, V, Fe, Ni, Mn, Li, and Be were mainly from detrital. Ca, Sr, and $\mathrm{Mg}$ concentrations were controlled by chemical weathering processes. Na came mainly from salt precipitation caused by a decline in water level. Enrichment factors for Pb and P in recent deposits are large, indicating they were influenced by human activies. Geochemical conditions during the past century can be divided into three stages: i) From ca. 1900 to the1950s element concentrations varied widely and frequently. In general, concentrations of typical mobile elements $\mathrm{Ca}$, Sr, and Mg stay relatively high whereas values for other elements remained relatively low. This was interpreted to reflect variable climate under conditions of weak surface erosion intensity. ii) From the 1950s to the early 2000s, element concentrations display less variability. The Al, K, Ba, Ti, P, Cr, V, Fe, Ni, Mn, Co, $\mathrm{Cu}, \mathrm{Li}, \mathrm{Zn}, \mathrm{Be}, \mathrm{Pb}$, and $\mathrm{Na}$ contents were generally higher, whereas contents of $\mathrm{Ca}, \mathrm{Sr}$, and $\mathrm{Mg}$ were on average lower. This indicates that the regional environment was conducive to surface erosion. Enrichment of trace metals and major elements in the sediment reflects enhanced human activities. iii) In the last decade, $\mathrm{Pb}$ and $\mathrm{P}$ exhibited a great increase, possibly associated with the input from fossil fuel combustion, sewage discharge and non-point-source pollution in the watershed. The lake volume decreased substantially because of groundwater extraction for municipal water, which resulted in a marked increase in salinity and enhanced Na precipitation.
\end{abstract}

Key words: Chaiwopu Lake; China; environmental change; geochemistry; lake sediment; paleolimnology.

Received: July 2015. Accepted: December 2015.

\section{INTRODUCTION}

Elements in lake sediments are ultimately from rock weathering, soil erosion, and anthropogenic sources (Karadede and Ünlü, 2000; Routh et al., 2004; Tylmann et $a l ., 2005)$. The geochemical composition of lake sediments can thus provide information about regional environmental changes over historical timescales (Smol et al., 1992; Battarbee et al., 1999; Last et al., 2001). In addition, some heavy metals are toxic to aquatic organisms, even in minute quantities, so changes in their loading or concentration could have ecosystem-wide implications. Therefore, sound environmental management requires an understanding of the sources of elements in lake sediments and the factors that influence their delivery to lakes.

Over the past several decades, the intensity of human activities has increased worldwide, which has influenced nutrient cycles and in some cases increased metal delivery to lakes. Stratigraphic study of lake sediments enables inference of long-term natural environmental variations and the impact of recent human activities on lakes and their catchments (Koinig et al., 2003). Considerable research has focused on determining the origin of elements in lake sed- iments of humid regions (Qu et al., 2001; Liu et al., 2003; Boyle et al., 2004; Yang et al., 2005; Wu et al., 2007). There has, however, been little study of element concentrations in lake sediments from arid regions, and records of heavy metal pollution in these areas are especially sparse.

In this study, we report element concentrations in sediments from Chaiwopu Lake, China, to reveal the geochemical sources of elements and the influences of climate change and human activities on the arid northwest region of the country. We used mathematical and statistical methods, as well as enrichment factors (EFs), to analyze stratigraphic fluctuations in elemental concentrations in the lake sediments and infer temporal variations in climate and anthropogenic pollution over the past century.

\section{METHODS}

\section{Regional setting}

Chaiwopu Lake is an inland, closed water body in the central Tianshan Mountains of northwest China. It is located in an important airflow exchange channel between the northern and southern Xinjiang region, in an arid region of 
the country (Fig. 1a) (Wang and Dou, 1998). The lake is circular in shape and has a flat bottom. According to a field survey in 2008 (Wu et al., 2014), the water body lies at 1089 $\mathrm{m}$ above sea level, is $6.8 \mathrm{~km}$ long by $5.6 \mathrm{~km}$ wide, and has a surface area of $27 \mathrm{~km}^{2}$. The maximum depth is $4 \mathrm{~m}$, and the water volume is $0.63 \times 10^{8} \mathrm{~m}^{3}$ (Wu et al., 2014). The water type is $\mathrm{SO}_{4}$-Na- II , and salinity was $6.22 \mathrm{~g} / \mathrm{L}$ in 2008 .
The area has a temperate continental arid climate, and is rich in wind resources, with an annual average wind speed of $6.0 \mathrm{~m} \mathrm{~s}^{-1}$ (Wang and Dou, 1998). The catchment area is approximately $1700 \mathrm{~km}^{2}$, and the watershed/lake ratio is 63 . Chaiwopu Lake is mainly supplied by glacier meltwater and snow from the North Mountains. The groundwater has been exploited since AD 1993 by the
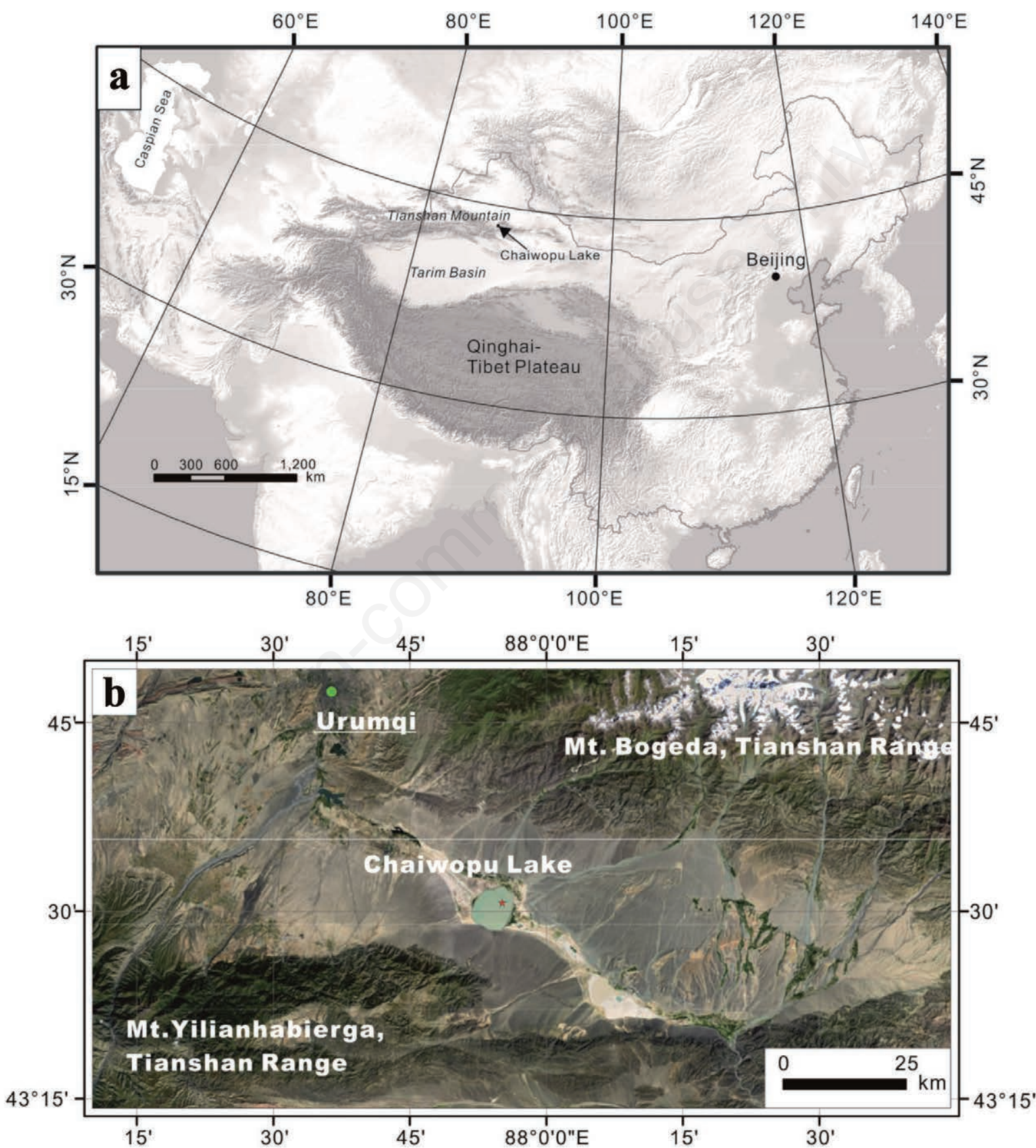

Fig. 1. Map showing (a) the geographic location of Chaiwopu Lake in northeast China and (b) the site in the lake where core DC01 was collected. 
municipality of Urumqi, the provincial capital of the Xinjiang Uyghur Autonomous Region, China. Since then, the Chaiwopu region has become the second largest source of urban water supply in Urumqi.

\section{Sampling and analysis}

In January 2013, sediment core DC01 (81 cm long) was collected from the northeastern part of the lake with a percussion-type piston corer (Fig. 1b) that was fitted with a $60-\mathrm{mm}$ internal diameter Perspex tube. After being collected, the core was kept in a vertical position in the field and carefully sectioned into $1-\mathrm{cm}$ intervals. Subsamples were kept in tightly sealed plastic containers and were stored at a temperature of $4^{\circ} \mathrm{C}$ prior to analysis of ${ }^{137} \mathrm{Cs}$ and elemental composition.

Subsamples of dried sediment were analyzed for ${ }^{137} \mathrm{Cs}$ content by direct gamma spectrometry. This was accomplished using Ortec HPGe GWL series well-type, coaxial, low-background intrinsic germanium detectors (Appleby et al. 1986). Total contents of elements in $\sim 0.125$-g DC01 samples (dried at $105^{\circ} \mathrm{C}$, ground to $200-\mu$ mesh size) were determined after treatment with $\mathrm{HF}-\mathrm{HNO}_{3}-\mathrm{HClO}_{4}$ in a Berghof MWS-3 microwave digester, followed by analysis using a Leeman Labs Profile ICP-AES. The error for duplicate samples was $<5 \%$. Analyses were carried out at the State Key Laboratory of Lake Science and Environment, Nanjing Institute of Geography and Limnology, Chinese Academy of Sciences.

\section{Statistical analysis and EF calculation}

Cluster analysis and factor analysis have been used widely in geochemical and environmental studies as an effective way to determine relationships among multi-dimensional data, and these methods aid in identification of the geochemical sources of samples (Liu et al., 2003; Wu, 2007b; Qu et al., 2001; Yang et al., 2005; Ma et al., 2013). Cluster analysis can classify a dataset into several clusters that exhibit similarities. Factor analysis is a powerful method to extract a small number of latent factors in multivariate data by extracting eigenvalues and eigenvectors, with maximum variance and minimum data loss (Gallego et al., 2002; Kowalkowski et al., 2006; Chen et al., 2008).

EFs were calculated as the ratio of the element concentration in recent sediment samples, to the natural, background concentration (Covelli et al., 1997; MilHomens et al., 2006; Ma et al., 2013b). Al is mainly derived from alumino-silicates, which are extremely immobile in the earth surface. For this reason, $\mathrm{Al}$ is often used as a reference element (Covelli et al., 1997; Muller et al., 2006). In this study, trace metals and major elements were normalized to $\mathrm{Al}$ to distinguish the anthropogenic portion of metals and $\mathrm{P}$ from natural background concentrations. We used the average concentration values of elements from depths below $70 \mathrm{~cm}$ as background values to calculate $\mathrm{EF}_{\mathrm{C}}, \mathrm{EF}_{\mathrm{Pb}}, \mathrm{EF}_{\mathrm{Zn}}, \mathrm{EF}_{\mathrm{Cu}}$, and $\mathrm{EF}_{\mathrm{P}}$

\section{RESULTS}

\section{Chronology of the sediment profile}

${ }^{137} \mathrm{Cs}$ activity was first detected at a depth of $43 \mathrm{~cm}$ in the core, which was assigned a date of AD 1954 to coincide with the first appearance on the earth surface of this artificial radionuclide from atmospheric atomic bomb testing (Appleby et al. 2002). The ${ }^{137} \mathrm{Cs}$ activity profile exhibited a peak at $36 \mathrm{~cm}$ depth, which was assigned a date of AD 1963, which coincides with the year of maximum global atmospheric ${ }^{137} \mathrm{Cs}$ fallout (Appleby et al., 2002). The core was collected in January 2013, so the top of the core was assigned a date of AD 2013. The bottom of the core $(81 \mathrm{~cm})$ was assigned an estimated date of ca. AD 1900 by downward extrapolation of the average sedimentation rate. The four dated horizons, i.e. 1900, 1954, 1963 and 2013, were used to provide a general age-depth framework for the Chaiwopu Lake sediment core (Fig. 2).

\section{Geochemical zones of the Chaiwopu Lake core}

Major and trace element concentrations, as mass per unit dry weight in Chaiwopu Lake sediments, are presented in Fig. 2. Concentrations of $\mathrm{Al}, \mathrm{K}, \mathrm{Be}, \mathrm{Ba}, \mathrm{Ti}, \mathrm{Na}$, $\mathrm{Mg}, \mathrm{Zn}, \mathrm{V}, \mathrm{Pb}, \mathrm{Co}, \mathrm{Cr}, \mathrm{Ni}$, and $\mathrm{Fe}$ have, in general, lower values and fluctuate widely from ca. 1900 to the 1950s. In addition, these elements have generally higher and more stable values during the period from the 1950 s to the 2000s, but show declines in concentration after the 2000s. Both $\mathrm{Ca}$ and $\mathrm{Sr}$ concentrations are negatively correlated with $\mathrm{Al}$ during the $20^{\text {th }}$ century, but all three values dropped rapidly after year 2000 . Na was relatively stable before the 2000s, but increased substantially from 2000 to 2013.

Element contents were standardized using z-scores. Euclidean distance was calculated and the Ward method was selected for cluster analysis. Hierarchical clustering was then performed (Fig. 3). The elements can be divided into three groups. The first group includes $\mathrm{Al}, \mathrm{K}, \mathrm{Ba}, \mathrm{Ti}$, $\mathrm{P}, \mathrm{Cr}, \mathrm{V}, \mathrm{Fe}, \mathrm{Ni}, \mathrm{Mn}, \mathrm{Co}, \mathrm{Cu}, \mathrm{Li}, \mathrm{Zn}, \mathrm{Be}$, and $\mathrm{Pb}$. Among the above elements, $\mathrm{Al}, \mathrm{K}, \mathrm{Ba}$ and Ti have close associations with silicate minerals. The second group consists of $\mathrm{Ca}, \mathrm{Mg}$, and $\mathrm{Sr}$ and displays stratigraphic trends opposite from the first group. The last group includes only $\mathrm{Na}$, which exhibited very different geochemical behavior compared with other elements in the sediments.

\section{DISCUSSION}

Chaiwopu Lake is circular in shape, has a flat bottom and is hydrologically closed. Therefore, a sediment core from the central part of the lake is probably representative of lakewide deposition. We used the vertical distribution 

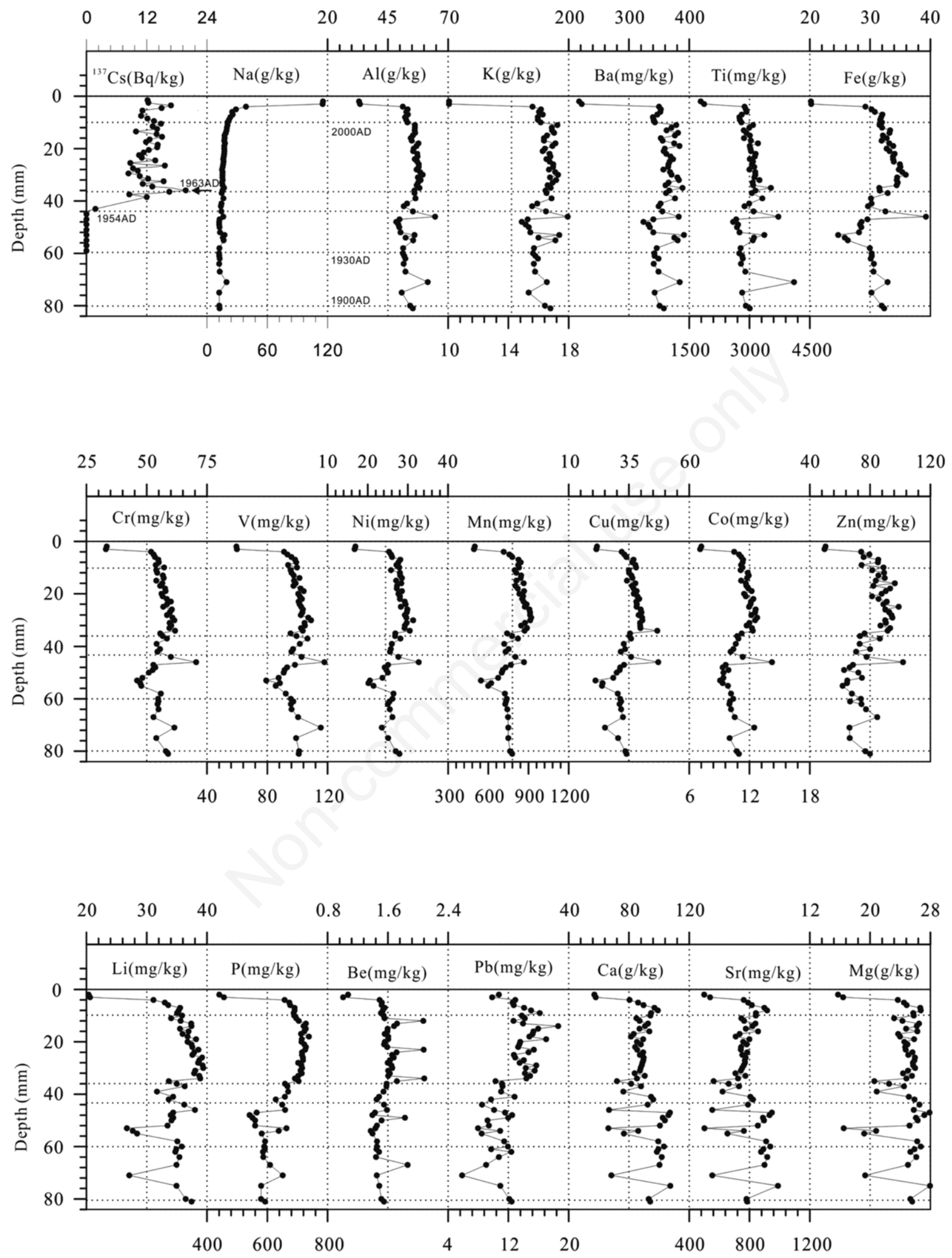

Fig. 2. ${ }^{137} \mathrm{Cs}$ activity and selected dates in core DC01, and selected element concentrations versus depth in the sediment. 
of trace and major elements from the sediment core taken in Chaiwopu Lake to discriminate between the influence of climate change and human activities on geochemical changes in the lake sediments over the past century. According to the results of cluster analysis, $\mathrm{Na}$ differed from the other elements. The origin of $\mathrm{Na}$ is not controlled by the input of natural chemical weathering products from the surrounding watershed. $\mathrm{Na}$ is associated with the amount of lake water and derives mainly from salt deposition. To better understand the relationships among the elements in Chaiwopu Lake sediments, factor analysis was applied to the transformed data and the results are presented in Supplementary Tab. 1. Three factors account for $90 \%$ of the total variance. As shown in the component loading plot of element composition in the Chaiwopu lake sediment (Supplementary Fig. 1), Na is unique in that loadings for all three factors were negative. In the evolution of this aridzone, closed-basin lake, the dominant sedimentary minerals followed the sequence carbonates-sulfates-chlorides through time. In the earlier evolutionary stage, calciummagnesium carbonates dominated mineral sedimentation. Meanwhile, natron and trona were deposited in small amounts. Contents of $\mathrm{Ca}$ and $\mathrm{Mg}$ were negatively correlated with elemental $\mathrm{Al}$ from the detrital mineral fraction. In the latter period, the lake water salinity increased as the water depth decreased, and sulfates (e.g., $\mathrm{Na}_{2} \mathrm{SO}_{4} \cdot 10 \mathrm{H}_{2} \mathrm{O}$, $\mathrm{Na}_{2} \mathrm{SO}_{4}$ ) began to precipitate. In 2008, the Chaiwopu Lake water was $\mathrm{SO}_{4}$-Na- II type and salinity was $6.22 \mathrm{~g} / \mathrm{L}$. In recent years, the shrinking of Chaiwopu Lake has accelerated. Sodium salts precipitated and the high concentration of $\mathrm{Na}$ in the top of the core contrasts with lower concentrations of other elements.

The first factor results from the content variation of elements $\mathrm{Al}, \mathrm{Ba}, \mathrm{K}, \mathrm{Ti}$, and $\mathrm{V}$, which have positive high loadings. Al is a typical lithogenic element and a major constituent of common silicate minerals. $\mathrm{Al}$ is usually present in the lattice of alumino-silicate minerals (Price et al., 1999). This indicates that elements $\mathrm{Al}, \mathrm{Ba}, \mathrm{K}, \mathrm{Ti}$,

\section{Dendrogram using Ward Linkage}

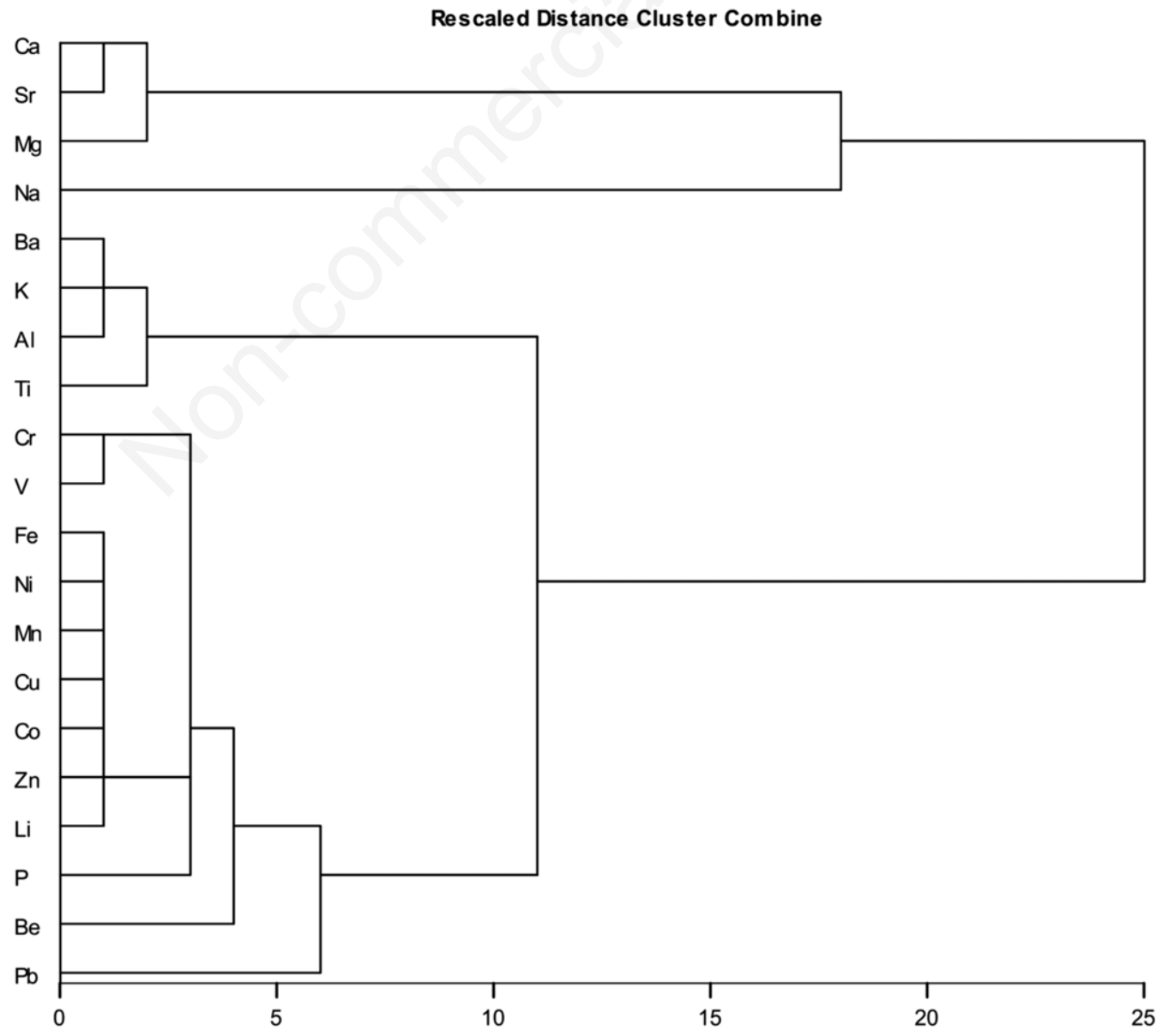

Fig. 3. Cluster analysis of the elements in sediment core DC01 from Chaiwopu Lake. 
and $\mathrm{V}$ are mainly of lithogenic origin, from land surface erosion in the drainage basin.

The second factor accounted for $33.82 \%$ of total variance, which mainly controlled the trace metals and major elements ( $\mathrm{Fe}, \mathrm{Cu}, \mathrm{Co}, \mathrm{Mn}, \mathrm{Ni}, \mathrm{Pb}$, and $\mathrm{Zn}$ ) and phosphorus. The trace metals and major elements also have high positive loadings for the first factor and showed slight positive correlation with $\mathrm{Al}$, the element of lithogenic origin. This indicates that they partially derived from lithogenic sources bound in alumino-silicate minerals. Values for $\mathrm{EF}_{\mathrm{P}}$ are $>1$ beginning about $\mathrm{AD} 1950 \mathrm{AD}$, which is correlated with the first expansion of arable land in Urumqi (Fig. 4). With the development of industry and agriculture, $\mathrm{EF}_{\mathrm{Cu}}, \mathrm{EF}_{\mathrm{Cr}}, \mathrm{EF}_{\mathrm{Pb}}$, and $\mathrm{EF}_{\mathrm{Zn}}$ values are slightly $>1$ beginning $c a$. AD 1970, suggesting that heavy metals became enriched as anthropogenic sources increased. The third factor mainly controlled variations of $\mathrm{Ca}, \mathrm{Sr}$, and $\mathrm{Mg}$ with high positive loadings. $\mathrm{Ca}, \mathrm{Mg}$, and $\mathrm{Sr}$ are major elements of carbonate (sedimentary) rocks that end up in the lake sediment, in part, from authigenic mineral precipitation from the lake water (Ip et al., 2007; Rubio et al., 2000). We used the $\mathrm{C}$ index $(\mathrm{CI}), \mathrm{CI}=(\mathrm{Al}+\mathrm{K}+\mathrm{Fe}) /$
$(\mathrm{Al}+\mathrm{K}+\mathrm{Fe}+\mathrm{Ca}+\mathrm{Mg})$, as a measure of the relative input of detrital terrigenous material.

Using stratigraphic variations in EFs and CI, we divided the sediment profile of the last century into three stages. In the earliest stage (ca. 1900-1950), lake change was controlled largely by natural factors because of weak economic development. This is inferred from the relatively low concentrations of trace metals and major elements, values that were used to characterize background concentrations. Al, K, Ba, Ti, P, Cr, V, Fe, Ni, Mn, Co, Cu, $\mathrm{Li}, \mathrm{Zn}, \mathrm{Be}, \mathrm{Pb}$, and $\mathrm{Na}$ were relatively low, whereas contents of $\mathrm{Ca}, \mathrm{Sr}$, and $\mathrm{Mg}$ were relatively high. According to the tree-ring record of adjacent regions, climate in this period was relatively dry (Li et al., 2006). The CI was lower than in the following period. Climate in this stage is inferred to have been variable, and the intensity of surface erosion was weak. In this stage, there were two periods with low heavy-metal concentrations, associated with high values of the CI index. This may have resulted from intense dust storms that carried large inputs of light clastic minerals into the lake.

The second stage was from the 1950s to the 2000s. The

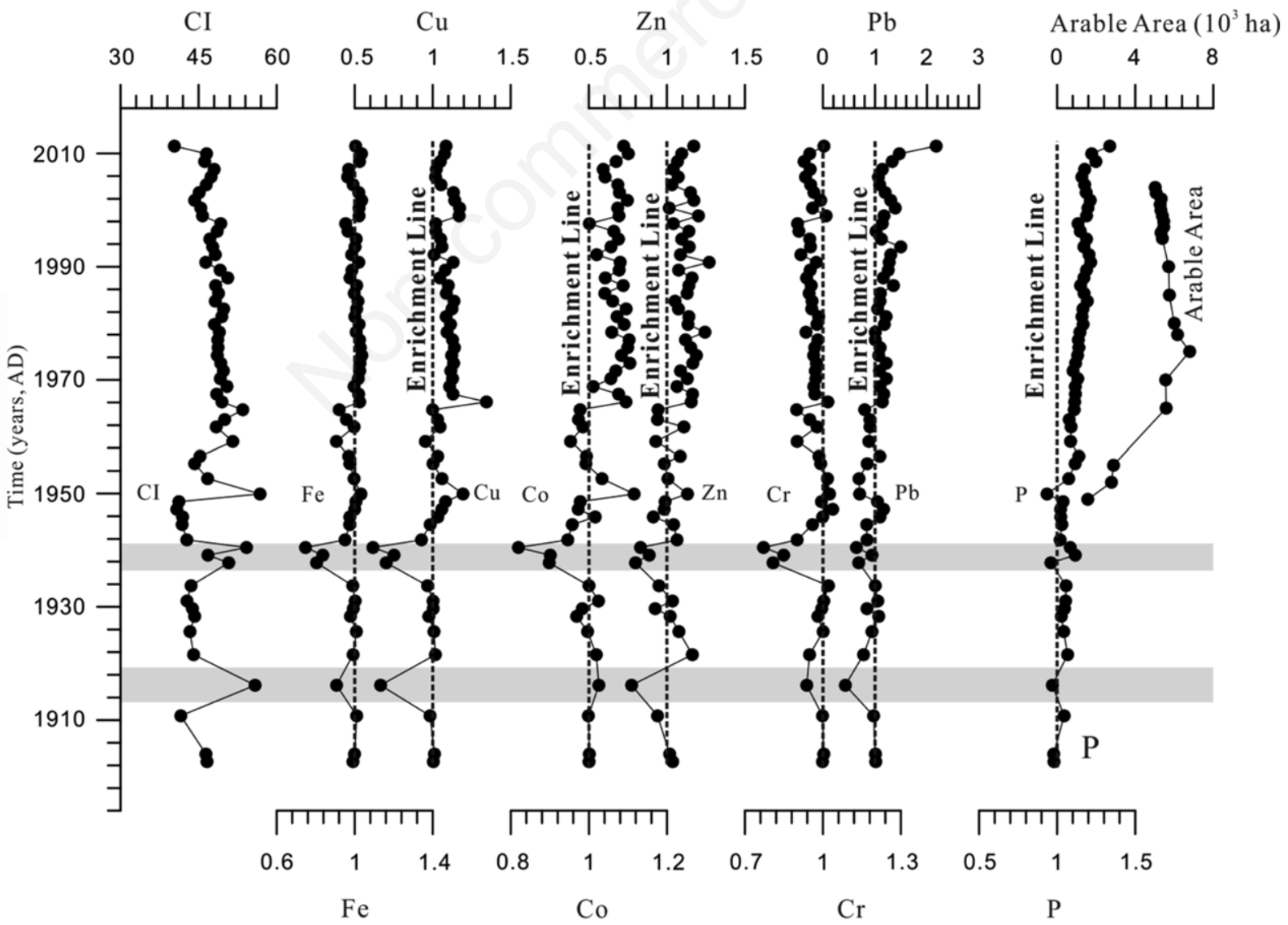

Fig. 4. Enrichment factors for trace metals and major elements in the Chaiwopu Lake sediment core. 
climate became warmer and moister according to instrumental data, and changes to glaciers and lakes in this area began in the 1950s (Shi et al., 2007). Compared to the first stage, $\mathrm{Al}, \mathrm{K}, \mathrm{Ba}, \mathrm{Ti}, \mathrm{P}, \mathrm{Cr}, \mathrm{V}, \mathrm{Fe}, \mathrm{Ni}, \mathrm{Mn}, \mathrm{Co}, \mathrm{Cu}, \mathrm{Li}, \mathrm{Zn}$, $\mathrm{Be}, \mathrm{Pb}$, and $\mathrm{Na}$ are all higher, whereas the contents of $\mathrm{Ca}$, $\mathrm{Sr}$, and $\mathrm{Mg}$ are lower. The higher $\mathrm{CI}$ indicates enhanced inputs of detrital terrigenous materials. In supergene environments, $\mathrm{Ca}, \mathrm{Sr}$, and $\mathrm{Mg}$ are the typical mobile elements, which are characterized by increased concentrations with increasing land surface leaching. The concentrations of typical stable elements $\mathrm{Al}, \mathrm{K}, \mathrm{Ti}$ are associated with inputs of detrital material. Eluviation and deposition of mobile elements directly influences the relative mass concentrations of stable elements. In this stage, human activities like fishing, agriculture, and industry were well developed. This recent enrichment of $\mathrm{P}$ illustrates that human activities have enhanced nutrient delivery to the lake during the past several decades. The anthropogenic $\mathrm{Pb}$ were probably from the fossil fuel combustion, sewage discharge and non-point source pollution of watershed through atmospheric deposition and surface runoff.

The third stage was from the 2000 s to present. In this stage, $\mathrm{Pb}$ and $\mathrm{P}$ exhibited a substantial increase. The instrumental record shows that water quantity decreased markedly and salinity increased dramatically during the last 10 years. This led to abundant $\mathrm{Na}$ precipitation in the lake sediment and a decline in carbonate content at the same time.

\section{CONCLUSIONS}

Geochemical analysis of a short sediment core from Chaiwopu Lake in arid northwest China was used to infer climate changes and human activities in the region over the last century. $\mathrm{Ca}, \mathrm{Sr}$, and $\mathrm{Mg}$ were derived from catchment weathering and subsequent endogenic deposition. $\mathrm{Pb}$ and $\mathrm{P}$ were enriched in post-1950 deposits and were influenced by human activities in the drainage basin. Sodium in the sediment is mainly from salt deposition, and has been highly enriched in the sediments in the 2000 s, in accordance with a documented salinity increase in the lake water. These recent chemical trends were caused by water consumption by Urumqi, which reduced the volume of the lake. $\mathrm{Al}$ and other elements in the sediment were derived from detrital sources.

The past century was subdivided into three stages. During the first stage, $c a$. 1900-1950, the climate was variable and the intensity of land surface erosion was weak. During the second stage, ca. 1950-2000, the surrounding environment was stable and conducive to surface erosion. Human activities first began to influence the lake during this stage, as seen in the enrichment of $\mathrm{Pb}$ and $\mathrm{P}$ in the lake sediment. The third stage is represented by sediments deposited in the last decade. During this recent period, the lake volume shrank, Na precipitated from the water column and became enriched in the sediment, and human activities became the main factor influencing the geochemistry of the lake.

\section{ACKNOWLEDGEMENTS}

We thank Mark Brenner, an anonymous reviewer and the journal editors for their helpful comments and suggestions, which improved the manuscript. This study was supported by the West Light Foundation of The Chinese Academy of Sciences (2015-XBQN-B-18) and the National Natural Science Foundation of China (41501221; 41471173). The authors also gratefully acknowledge the supports of the High-level Talents Introduction Project in Xinjiang Uygur Autonomous Region, China.

\section{REFERENCES}

Appleby PG, 2002. Chronostratigraphic techniques in recent sediments, p. 171-203. In: W.M. Last and J.P. Smol (eds.), Tracking environmental change using lake sediments. Volume 1, Basin analysis, coring, and chronological techniques. Springer.

Appleby PG, Nolan PJ, Gifford DW, Godfrey MJ, Oldfield F, Anderson NJ, Battarbee RW, 1986. ${ }^{210} \mathrm{~Pb}$ dating by low background gamma counting. Hydrobiologia 143:21-27.

Battarbee RW, 1999. The importance of palaeolimnology to lake restoration. Hydrobiologia 395-396:149-159.

Boyle JF, Rose NL, Appleby P, Birks HJB, 2004. Recent environmental change and human impact on Svalbard: the lakesediment geochemical record. J Paleolimnol. 31:515-530.

Chen T, Liu X, Zhu M, Zhao K, Wu J, Xu J, Huang P, 2008. Identification of trace element sources and associated risk assessment in vegetable soils of the urban-rural transitional area of Hangzhou, China. Environ. Pollut. 151:67-78.

Covelli S, Fontolan G, 1997. Application of a normalization procedure in determining regional geochemical baselines. Environ. Geol. 30:34-45.

Gallego JL, Ordóñez A, Loredo J, 2002. Investigation of trace element sources from an industrialized area (Aviles, northern Spain) using multivariate statistical methods. Environ. Int. 27:589-596.

Ip CC, Li X, Zhang G, Wai OW, Li Y, 2007. Trace metal distribution in sediments of the Pearl River Estuary and the surrounding coastal area, South China. Environ. Pollut. 147:311-323.

Karadede H, Ünlü E, 2000. Concentrations of some heavy metals in water, sediment and fish species from the Atatürk Dam Lake (Euphrates), Turkey. Chemosphere 41:1371-1376.

Kowalkowski T, Zbytniewski R, Szpejna J, Buszewski B, 2006. Application of chemometrics in river water classification. Water Res. 40:744-752.

Last WM, Smol JP, Birks HJB, 2001. Tracking environmental change using lake sediments. 2. Physical and geochemical methods. Springer, New York: 504 pp.

Li J, Gou X, Cook ER, Chen F, 2006. Tree-ring based drought reconstruction for the central Tien Shan area in northwest China. Geophys. Res. Lett. 33:L07715.

Liu W, Li X, Shen Z, Wang D, Wai O, Li Y, 2003. Multivariate 
statistical study of heavy metal enrichment in sediments of the Pearl River Estuary. Environ. Pollut. 121:377-388.

Ma L, Wu J, Abuduwaili J, 2013. Geochemical evidence of the anthropogenic alteration of element composition in lacustrine sediments from Wuliangsu Lake, north China. Quatern. Int. 2013:107-113.

Mil-Homens M, Stevens R, Abrantes F, Cato I, 2006. Heavy metal assessment for surface sediments from three areas of the Portuguese continental shelf. Cont. Shelf Res. 26:1184-1205.

Muller J, Wüst RAJ, Weiss D, Hu Y, 2006. Geochemical and stratigraphic evidence of environmental change at Lynch's Crater, Queensland, Australia. Global Planet. Change 53: 269-277.

Price N, Brand T, Pates JM, Mowbray S, Theocharis A, Civitarese G, Miserocchi S, Heussner S, Lindsay FS, 1999. Horizontal distributions of biogenic and lithogenic elements of suspended particulate matter in the Mediterranean Sea. Prog. Oceanogr. 44:191-218.

Qu W, Dickman M, Wang S, 2001. Multivariate analysis of heavy metal and nutrient concentrations in sediments of Taihu Lake, China. Hydrobiologia 450:83-89.

Routh J, Meyers PA, Gustafsson Ö, Baskaran M, Hallberg R, Schöldström A, 2004. Sedimentary geochemical record of human-induced environmental changes in the Lake Brunnsviken watershed, Sweden. Limnol. Oceanogr. 49: 1560-1569.
Rubio B, Nombela M, Vilas F, 2000. Geochemistry of major and trace elements in sediments of the Ria de Vigo (NW Spain): an assessment of metal pollution. Mar. Pollut. Bull. 40: 968-980.

Shi Y, Shen Y, Kang E, Li D, Ding Y, Zhang G, Hu R, 2007. Recent and future climate change in northwest China. Climatic Change 80:379-393.

Smol JP, 1992. Paleolimnology: an important tool for effective ecosystem management. J. Aquat. Ecos. Health 1:49-58.

Tylmann W, 2005. Lithological and geochemical record of anthropogenic changes in recent sediments of a small and shallow lake (Lake Pusty Staw, northern Poland). J. Paleolimnol. 33:313-325.

Wang S, Dou H, 1998. [Lakes in China].[Book in Chinese].Science Press, Beijing.

Wu J, Liu W, Zeng H, Ma L, Bai R, 2014. Water Quantity and Quality of Six Lakes in the Arid Xinjiang Region, NW China. Environ. Proc. 1:115-125.

Wu Y, Hou X, Cheng X, Yao S, Xia W, Wang S, 2007. Combining geochemical and statistical methods to distinguish anthropogenic source of metals in lacustrine sediment: a case study in Dongjiu Lake, Taihu Lake catchment, China. Environ. Geology 52:1467-1474.

Yang H, Rose N, 2005. Trace element pollution records in some UK lake sediments, their history, influence factors and regional differences. Environ. Int. 31:63-75. 